\title{
Analisis Profitabilitas Untuk Mengukur Kinerja Keuangan Manajemen Hotel (Studi Kasus pada UNY-Hotel Yogyakarta).
}

\author{
Ismani $^{1}$ \\ Ngadirin Setiawan ${ }^{2}$ \\ Andian Ari Istiningrum ${ }^{3}$
}

\begin{abstract}
Abstrak
The purpose of this research is to measure financial performance of UNY-Hotel management by using profitability ratios, such as Net Profit Margin (NPM) and Return of Total Assets (ROA). The research is an evaluative research that is done by analyzing financial statement of UNY-Hotel and interviewing management in order to get more deeply information. The result of this research shows that financial performance of UNY-Hotel is low due to NPM at $26.89 \%$ that is lower than the target at $40 \%$ and ROA at $6.41 \%$ that is lower than the interest rate $(10 \%-12 \%$ per annum). This result indicates that there is inefficiency in managing assets and expenses.
\end{abstract}

\section{Kata Kunci: kinerja keuangan, profitabilitas, net profit margin, return on asset, tingkat perputaran aset}

\section{A. PENDAHULUAN}

Masalah pokok yang dihadapi dalam pengelolaan atau manajemen hotel adalah rendahnya kinerja manajemen, baik ditinjau dari aspek kepatuhan terhadap pelaksanaan kerja maupun pada pengelolaan keuangan hotel. Rendahnya kinerja manajemen hotel UNY-Hotel antara lain disebabkan beberapa faktor, yaitu antara lain dapat diidentifikasikan sebagai berikut: (1) kurangnya tanggung jawab dan komitmen pihak manajemen terhadap ketentuan dan peraturan yang berlaku, (2) sarana prasarana pendukung operasional hotel belum memadai, (3) pengetahuan dan keterampilan karyawan dalam pelaksanaan operasional manajemen hotel belum memadai, (4) masih lemahnya pengawasan pihak-pihak terkait dalam operasional hotel, (5) kegiatan pemeriksaan atau audit operasional atas manajemen hotel belum dapat dilaksanakan secara berkala, (6) masih kurangnya pengawasan terhadap pelaksanaan manajemen keuangan dan akuntansi hotel, dan (7) pengendalian intern masih lemah.

Masalah lainnya adalah dengan ketidaktercapaian kinerja manajemen hotel UNY-Hotel akan berdampak pada tidak efektifnya tujuan yang diharapkan oleh lembaga UNY untuk meningkatkan income generating yang sekaligus meningkatkan kesejahteraan warga civitas akademika. Tujuan didirikannya bidang usaha UNY-Hotel pada hakekatnya adalah sebagai salah satu sumber pendapatan Universitas Negeri Yogyakarta sebagai PTN Badan Layanan Umum (BLU) melalui usaha perhotelan untuk mendukung keberlangsungan kegiatan akademik di UNY sejalan dengan status UNY sebagai Badan Layanan Umum sekaligus meningkatkan mutu akademik dan peningkatan pendapatan UNY. Agar pengelolaan UNYHotel dilaksanakan secara profesional, maka pengelolaannya diserahkan kepada pihak yang sudah berpengalaman dan terpercaya secara publik yaitu kepada pihak manajemen CV Smart Manajemen Indonesia (SMI) dengan berlandaskan pada Surat Perjanjian Kerjasama

\footnotetext{
${ }^{1}$ Dosen Jurusan Pendidikan Akuntansi - Universitas Negeri Yogyakarta

${ }^{2}$ Dosen Jurusan Pendidikan Akuntansi - Universitas Negeri Yogyakarta

${ }^{3}$ Dosen Jurusan Pendidikan Akuntansi - Universitas Negeri Yogyakarta
} 
Operasional Nomor UNY 346/H.34.39/MOU/2009 dan Nomor SMI.002/SMI/ VII/2009 tertanggal 21 Juli 2009.

Ada perbedaan prinsip pengelolaan antara hotel yang dikelola oleh perguruan tinggi dengan yang dikelola oleh swasta. Pada umumnya pengelolaan hotel yang didirikan perguruan tinggi disamping bersifat komersial juga bertujuan untuk meningkatkan mutu akademik, sedangkan yang dikelola oleh swasta murni semata-mata hanya bertujuan komersial. Hotel adalah suatu bentuk bangunan, perusahaan atau badan usaha akomodasi yang menyediakan pelayanan jasa penginapan, penyedia makanan dan minuman serta fasilitas jasa lainnya dimana semua pelayanan itu diperuntukkan bagi masyarakat umum, baik mereka yang bermalam di hotel tersebut ataupun mereka yang hanya menggunakan fasilitas tertentu yang dimiliki hotel itu. Menurut SK Menteri Parpostel (No. Km.94/HK103/MPPT 1987) yang dimaksud dengan hotel adalah salah satu jenis akomodasi yang mempergunakan sebagian atau keseluruhan bagian untuk jasa pelayanan penginapan, penyedia makanan dan minuman serta jasa lainnya bagi masyarakat umum yang dikelola secara komersial. Setiap pengusaha hotel juga harus menyampaikan laporan tingkat hunian kamar dan harga rata-rata kamar setiap satu bulan kepada Kepala Dinas Pariwisata dan Kebudayaan. Selain itu, juga harus menyampaikan Laporan Kegiatan Usaha (LKU) setiap satu tahun sekali kepada Kepala Dinas Pariwisata dan Kebudayaan. Setiap pengusaha hotel harus menyediakan tempat/ ruang (outlet) penjualan barang-barang kerajinan (handicraft) produk Usaha Kecil Menengah. Dalam kaitannya dengan hotel yang dikelola oleh perguruan tinggi, maka pihak manajemen disamping memiliki kewajiban untuk menyampaikan laporan kepada Dinas Pariwisata dan Kebudayaan juga berkewajiban untuk menyampaikan laporan secara rutin kepada pihak pimpinan universitas. Disamping itu, pihak Universitas juga memiliki kewenangan untuk melakukan evaluasi atas kinerja keuangan hotel secara berkala agar pengelolaan hotel dapat berjalan secara efektif dan efisien serta sesuai dengan tujuan dan peraturan perundangundangan berlaku. Dari hasil evaluasi tersebut diharapkan dapat meningkatkan kinerja manajemen dalam menjalankan operasional hotel.

Atas dasar beberapa permasalahan di atas maka dipandang perlu untuk melakukan kajian dalam bentuk penelitian ini, yang selanjutnya diberi judul: Analisis Profitabilitas Untuk Mengukur Kinerja Keuangan Manajemen Hotel (Studi Kasus pada UNY-Hotel Yogyakarta).

Berdasarkan latar belakang masalah di atas maka selanjutnya dapat dirumuskan permasalahan sebagai berikut: Bagaimana Kinerja Keuangan Manajemen UNY-Hotel dengan menggunakan rasio profitabilitas Net Profit Margin dan Return on Total Assets pada tahun 2011 ? Penelitian ini bertujuan utuk mengukur kinerja keuangan manajemen UNY-Hotel dengan menggunakan rasio profitabilitas Net Profit Margin dan Return on Total Assets pada tahun 2011.

\section{B. KAJIAN TEORI \\ Kinerja Perusahaan}

Penilaian kinerja pada dasarnya merupakan penilaian perilaku manusia dalam melaksanakan peran yang dimainkannya dalam mencapai tujuan organisasi atau perusahaan. Penilaian kinerja menurut Mulyadi (2002) adalah penentuan secara periodik efektifitas operasional suatu organisasi, bagian organisasi dan karyawannya berdasarkan sasaran, standar dan kriteria yang ditetapkan sebelumnya. Karena organisasi pada dasarnya dijalankan oleh manusia, maka penilaian kinerja sesungguhnya merupakan penilaian atas perilaku manusia dalam melaksanakan peran yang mereka mainkan dalam organisasi. Sedangkan pengertian kinerja keuangan adalah penentuan ukuran-ukuran tertentu yang dapat mengukur keberhasilan suatu perusahaan dalam menghasilkan laba. Dalam mengukur kinerja keuangan 
perlu dikaitkan antara organisasi perusahaan dengan pusat pertanggungjawaban. Dalam melihat organisasi perusahaan dapat diketahui besarnya tanggung jawab manajer yang diwujudkan dalam bentuk prestasi kerja keuangan. Lebih lanjut Mulyadi (1997) menyebutkan bahwa tujuan penilaian kinerja adalah: (1) untuk memotivasi karyawan dalam mencapai sasaran organisasi dan dalam mematuhi standar perilaku yang telah ditetapkan sebelumnya agar membuahkan tindakan dan hasil yang diinginkan, (2) standar perilaku dapat berupa kebijakan manajemen atau rencana formal yang dituangkan dalam anggaran, dan (3) penilaian kinerja dilakukan untuk menekan perilaku yang tidak semestinya dan untuk merangsang dan menegakkan perilaku yang semestinya diinginkan melalui umpan balik hasil kinerja dan waktu serta penghargaan baik yang bersifat instrinsik maupun ekstrinsik. Menurut Ikatan Akuntansi Indonesia (SAK, 2007) aspek kinerja keuangan dapat dilihat melalui beberapa aspek, antara lain: (a) pengelolaannya atau manajemennya, (b) perubahan potensi sumber daya yang ada (kemampuan perusahaan dalam menghasilkan kas dan setara kas), (c) efektifitas sumber daya manusia yang berperan sebagai pengolah sumber daya ekonomi, dan (d) laporan keuangan (Neraca, Laporan Laba Rugi, Laporan Arus Kas, dan Laporan Perubahan Ekuitas).

\section{Kinerja Keuangan Perusahaan}

Dalam sistem perencanaan dan pengendalian manajemen, ada empat pusat pertanggungjawaban yang perlu mendapatkan perhatian, yaitu: pusat pertanggungjawaban terhadap pendapatan, pusat pertanggungjawaban terhadap biaya, pusat pertanggungjawaban terhadal laba, dan pusat pertanggungjawaban terhadap investasi. Dalam kaitannya dengan pusat pertanggungjawaban terhadap laba, maka penilaian kinerja keuangan dapat diukur dengan Rasio Profitabilitas. Rasio Profitabilitas adalah sekelompok rasio yang memperlihatkan pengaruh gabungan dari likuiditas, manajemen aset dan utang terhadap hasil operasi (Brigham dan Houston, 2001). Rasio Profitabilitas meliputi banyak rasio, dimana yang diganakan dalam penelitian ini adalah Rasio Net Profit Margin (RPM) dan Return on Total Assets (ROA)

Net Profit Margin (NPM) adalah perbandingan antara laba dengan penjualan. NPM menggambarkan tentang seberapa besar laba yang diperoleh perusahaan atas penjualan (income) selama periode tertentu. Semakin tinggi persentase NPM menunjukkan bahwa sebagian besar penjualan dapat dialokasikan pada laba dan hal ini menunjukkan bahwa perusahaan telah mampu menekan biaya secara efektif. Sebaliknya, jika persentase NPM kecil menunjukkan bahwa perusahaan tidak mampu menekan biaya yang berdampak pada tingginya beban perusahaan yang berakibat pada rendahnya kontribusi penjualan atas laba. NPM juga mengukur seluruh efisiensi, baik produksi, administrasi, pemasaran, pendanaan, penentuan harga maupun manajemen pajak (Dwi Prastowo dan Rifka Juliaty, 2002). NPM dapat dihitung dengan cara sebagai berikut:

$$
\mathrm{NPM}=\frac{\text { laba bersih }}{\text { penjualan }}
$$

Return on Total Assets ( ROA) mengukur kemampuan perusahaan dalam memanfatkan aktivanya untuk memperoleh laba. Rasio ini mengukur tingkat kembalian investasi yang telah dilakukan oleh perusahaan dengan menggunakan seluruh dana (aktiva) yang dimiliki. Rasio ini dapat diperbandingkan dengan tingkat bunga bank yang berlaku (Dwi Prastowo dan Rifka Juliaty, 2002). Sebagai contoh misalnya apabila besarnya angka ROI adalah $16 \%$ sedangkan rata-rata tingkat bunga umum $12 \%$, berarti kinerja manajemen menunjukkan berhasil atau baik. ROA dapat dihitung dengan menggunakan formula sebagai berikut: 


$$
\mathrm{ROA}=\frac{\text { laba bersih }}{\text { total aktiva }}
$$

Angka-angka rasio tidak akan mempunyai arti apabila tidak dibandingkan dengan angka yang lain. Angka lain yang bisa digunakan sebagai pembanding bisa berupa rata-rata industri. Menurut Abdul Halim dan Mamduh Hanafi (2003) ada banyak hal yang harus dipertimbangkan sebelum menentukan baik buruknya suatu angka ketika dibandingkan dengan rata-rata industri. Ada beberapa perusahaan yang memiliki kinerja buruk yang ikut masuk dalam perhitungan rata-rata industri. Selain itu, rata-rata industri juga bukan merupakan standar yang selalu baik yang seharusnya diikuti oleh perusahaan karena rata-rata industri hanya rata-rata perusahaan pada industri bersangkutan. Perusahaan yang memiliki kinerja baik biasanya adalah perusahaan yang memiliki rasio di atas rasio rata-rata industri, akan tetapi angka yang lebih rendah dibandingkan dengan angka rata-rata industri juga tidak selalu berarti jelek. Ada beberapa hal yang harus diperhatikan ketika menggunakan rata-rata industri:

1. Formula rasio industri berbeda diantara berbagai sumber, sementara tidak tersedia informasi tentang bagaimana rasio industri tersebut dihitung.

2. Perusahaan yang sama dapat menggunakan metoda penilaian atau pengakuan pendapatan yang berbeda yang dapat mengganggu dipenuhinya prinsip daya banding.

3. Perbedaan periode laporan keuangan yang digunakan oleh perusahaan-perusahaan yang dikelompokkan dalam satu kelompok industri.

4. Perusahaan dengan kebijakan keuangan yang berbeda dimasukkan dalam satu kelompok industri yang sama, misalnya perusahaan yang capital-intensive dimasukkan dalam satu kelompok industri perusahaan yang labor-intensive.

5. Beberapa data rata-rata industri ditentukan atas dasar sampel perusahaan yang jumlahnya sedikit sehingga tidak dapat mewakili kondisi industri yang sesungguhnya (Dwi Prastowo dan Rifka Juliaty, 2002).

Apabila angka rata-rata industri tidak tersedia, maka perusahaan bisa melakukan perbandingan dengan laporan keuangan perusahaan lain yang sejenis (Dwi Prastowo dan Rifka Juliaty, 2002). Biasanya perusahaan lain yang dipilih adalah perusahaan pesaing atau perusahaan yang menjadi leader dalam industri tersebut. Pembanding lain yang bisa digunakan adalah kriteria (target) yang ditetapkan perusahaan dan tingkat suku bunga bank.

\section{Pembatasan Kapasitas dan Pembatasan Kompetisi}

Dalam melakukan analisis terhadap ROA, analis perlu memperhatikan komponenkomponen yang membentuk ROA, yaitu Net Profit Margin (NPM) dan Tingkat Perputaran Aktiva (TPA). TPA adalah rasio yang digunakan untuk mengukur efisiensi penggunaan aktiva dalam rangka menghasilkan penjualan.

Perusahaan atau industri yang ditandai dengan biaya tetap yang besar dan membutuhkan periode yang lama untuk membangun atau menambah kapasitas produksi akan mempunyai pembatasan kapasitas. Ada batasan atas yang membatasi jumlah atau besarnya perputaran aktiva perusahaan. Bagi industri atau perusahaan semacam ini, diperlukan cara lain agar diperoleh ROA yang mampu menarik modal ke usaha tersebut. Cara tersebut adalah dengan menaikkan NPM. Dengan demikian, meskipun TPA perusahaan (industri) tersebut terbatas, perusahaan bisa memperoleh ROA yang tinggi dengan menaikkan NPMnya (Abdul Halim dan Mamduh M. Hanafi, 2003).

Pada situasi lain, perusahaan akan mengalami pembatasan karena adanya kompetisi. Kompetisi yang ketat akan membatasi NPM yang bisa dicapai. Untuk memperoleh ROA yang tinggi sehingga mampu menarik modal masuk ke perusahaan tersebut, perusahaan 
tersebut harus menaikkan TPAnya. Cara yang bisa ditempuh adalah dengan menurunkan biaya investasi (menurunkan biaya tetap overhead sehingga perusahaan bisa lebih fleksibel menghadapi naik turunnya penjualan dan melakukan integrasi vertikal atau horizontal untuk memperoleh penghematan biaya) dan melakukan pengendalian biaya. Dengan melakukan pengendalian biaya, perusahaan bisa menekan biaya produksi dan sekaligus bisa melakukan persaingan harga (Abdul Halim dan Manduh M. Hanafi, 2003).

\section{Strategi Bisnis}

Menurut Michael Porter dalam (Warren, Reeve, and Fess, 2006) ada dua macam strategi bisnis yang bisa digunakan oleh perusahaan, yaitu:

1. Strategi Diferensiasi

Perusahaan yang menggunakan straegi diferensiasi akan berusaha untuk mendesain dan menghasilkan produk atau jasa yang memiliki kekhususan atau karakteristik yang unik. Kondisi demikian akan membuat konsumen bersedia membayar harga yang lebih tinggi dibandingkan dengan harga umum. Agar strategi diferensiasi berhasil, sebuah produk atau jasa harus benar-benar unik atau dipersepsikan unik dalam hal kualitas, keandalan, citra atau desain.

2. Strategi Biaya Rendah

Berdasarkan strategi biaya rendah, sebuah perusahaan mendesain dan menghasilkan produk atau jasa dengan kualias yang diterima konsumen pada biaya produksi yang lebih rendah dibandingkan dengan para pesaingnya. Perusahaan bisa mencapai biaya rendah dengan berbagai cara, seperti: pengendalian anggaran yang ketat, penggunaan program pelatihan yang modern, penerapan teknologi manufaktur yang sederhana, menjalin hubungan dengan pemasok yang akan menghemat biaya .

\section{METODE PENELITIAN}

Penelitian ini merupakan penelitian evaluatif yaitu penelitian yang menilai profitabilitas hotel UNY-Hotel pada tahun 2011. Penelitian ini dilaksanakan selama 7 bulan efektif, yang dimulai tanggal 1 April sampai dengan 31 Oktober 2011. Tempat penelitian adalah UNYHotel yang beralamat di kampus UNY Karangmalang Yogyakarta. Secara umum metode pengumpulan data dilakukan dengan cara interview, dokumentasi, dan observasi. Kinerja profitabilitas diukur dengan menggunakan dua jenis rasio yaitu NPM dan ROA.

Net Profit Margin (NPM) adalah perbandingan antara laba dengan penjualan. NPM menggambarkan tentang seberapa besar laba yang diperoleh perusahaan atas penjualan selama periode tertentu. Semakin tinggi persentase NPM menunjukkan bahwa sebagian besar penjualan dapat dialokasikan pada laba, dan hal ini menunjukkan bahwa perusahaan telah mampu menekan biaya secara efektif, dan sebaliknya jika persentase NPM kecil menunjukkan bahwa perusahaan tidak mampu menekan biaya yang berdampak pada tingginya beban perusahaan yang berakibat pada rendahnya kontribusi laba atas penjualan. Dalam hal ini NPM diukur dengan membandingkan antara realisasi bagi hasil yang diterima UNY dengan target yang ditetapkan dalam PKO pasal 10 ayat 1,2, dan 3 yaitu dalam satu tahun target pendapatan profit sharing yang diterima UNY minimal sebesar $40 \%$.

Sedangkan ROA adalah merupakan perbandingan antara laba bersih dengan total aktiva. Dalam hal ini laba bersih yang dimaksudkan adalah perolehan laba bagi hasil yang diterima UNY dari pihak manajemen hotel. Semakin tinggi angka ROA berarti menunjukkan bahwa manajemen telah mampu mengoptimalkan kekayaan hotel UNY untuk mendapatkan laba dalam periode tertentu. Ukuran ROA umumnya dikaitkan dengan rata-rata tingkat bunga umum yang berlaku, dalam hal ini rata-rata tingkat bunga umum yang berlaku adalah dalam kisaran $10-12 \%$ per tahun. 


\section{HASIL PENELITIAN DAN PEMBAHASAN Hasil Penelitian}

Kinerja keuangan UNY-Hotel ditinjau dari analisis laporan keuangan, terutama rasio profitabilitas yang diukur dengan rasio Net Profit Margin (NPM) dan Return on Asset (ROA) memberikan gambaran sebagai berikut:

\section{Net Profit Margin (NPM)}

NPM merupakan hasil perbandingan antara laba bersih dengan penjualan. Jumlah bagi hasil yang diperoleh pihak UNY selama satu tahun sebesar Rp 631.188.398,40 sedangkan jumlah penjualan jasa hotel adalah sebesar Rp 2.199.744.512,00. Dengan demikian bahwa NPM UNY-Hotel adalah sebesar (631.188.398,40/ Rp2.199.744.512,00) x 100\% $=28,69 \%$.

Jumlah bagi hasi yang diterima UNY sebesar 28,69\% tersebut tidak memenuhi target sebagaimana pasal yang tercantum pada surat PKO yaitu minimal sebesar $40 \%$. Ketidak tercapaian target minimal tersebut menunjukkan bahwa komitmen manajemen UNY-Hotel tergolong lemah atau dengan kata lain kinerja manajemen UNY-Hotel rendah.

2. Return on Assets (ROA)

ROA adalah merupakan perbandingan antara laba bagi hasil dengan total aktiva yang digunakan untuk investasi awal hotel UNY. Laba bagi hasil yang diperoleh UNY sebesar Rp 631.188.398,40 dan nilai total aktiva awal hotel UNY termasuk penilaian tanah, bangunan, dan sarana pendukung memiliki nilai sekitar Rp 9.831.805.296. Dengan demikian besarnya ROA adalah $(\operatorname{Rp} 631.188 .398,40 / \operatorname{Rp} 9.831 .805 .296) \times 100 \%=6,41 \%$.

Jika dibandingkan dengan rata-rata tingkat bunga umum yang berlaku sebesar $10-12 \%$ per tahun maka nilai $6,41 \%$ tersebut masih dibawah rata-rata tingkat bunga umum sebesar $10 \%$. Hal ini menunjukkan bahwa kinerja manajemen UNY-Hotel masih di bawah kinerja umum yang diharapkan.

\section{Pembahasan}

\section{Net Profit Margin (NPM)}

NPM mengukur rupiah laba yang dihasilkan oleh setiap satu rupiah penjualan. NPM mengukur seluruh efisiensi baik itu produksi, administrasi, pemasaran, pendanaan, penentuan harga da manajemen pajak (Dwi Prastowo dan Rifka Juliaty, 2002). Rasio ini memberikan gambaran mengenai laba yang tersedia bagi pihak UNY dan CV Smart Manajemen Hotel sebagai persentase dari penjualan.

Hasil penelitian menunjukkan bahwa NPM yang berhasil dicapai UNY-Hotel adalah sebesar 26.89\%. Ditinjau dari aspek keuangan, NPM UNY-Hotel adalah tergolong cukup baik, yaitu rata-rata sekitar $28 \%$ - 32\%. Namun jika ditinjau dari target minimal NPM sebesar $40 \%$ berarti kinerja manajemen menunjukkan kurang baik karena tidak mencapai target yang ditetapkan dalam PKO. Rendahnya NPM UNY-Hotel mengindikasikan ketidakefisienan manajemen hotel dalam mengelola biaya dimana pendapatan yang diterima UNY-Hotel terlalu rendah untuk tingkat biaya yang dikeluarkan oleh UNY-Hotel.

\section{Return on Assets (ROA)}

ROA mengukur kemampuan UNY-Hotel dalam menghasilkan laba bersih berdasarkan tingkat aktiva tertentu. ROA yang tinggi menunjukkan efisiensi manajemen dalam mengelola aktiva yang dimiliki, sebaliknya ROA yang rendah mengindikasikan ketidakefisienan pengelolaan aktiva (Abdul Halim dan Mamduh M. Hanafi, 2003).

Hasil penelitian menunjukkan bahwa ROA UNY-Hotel adalah sebesar $6.41 \%$ Jika dibandingkan dengan tingkat bunga umum sekitar 10-12\%, maka ROA UNY-Hotel masih tergolong rendah. ROA bisa dipecah menjadi dua komponen, yaitu NPM dan Perputaran Aktiva. Perputaran Aktiva mencerminkan kemampuan perusahaan dalam menghasilkan 
penjualan berdasarkan aktiva yang dimilikinya. Karena ROA merupakan hasil kali dari NPM dengan perputaran aktiva, maka dapat dilihat bahwa perputaran aktiva dari Hotel-UNY adalah sebesar $23.84 \%$.

Industri perhotelan adalah industri yang tingkat kompetisinya cenderung ketat sehingga industri ini memiliki batasan kompetisi yang tinggi. Hal serupa juga dialami oleh UNYHotel. Kompetisi yang ketat akan menjadi hambatan dalam mencapai tingkat NPM yang tinggi. Hal ini bisa menjelaskan mengapa UNY-Hotel tidak bisa mencapai NPM yang telah ditargetkan sebesar 40\%. Rendahnya NPM ini memberikan kotribusi bagi rendahnya ROA. Oleh karena itu, satu-satunya cara yang bisa dilakukan oleh UNY-Hotel adalah dengan menaikkan tingkat perputaran aktivanya. Perputaran aktiva bisa ditingkatkan dengan cara menurunkan biaya investasi yaitu dengan mengendalikan biaya. Dengan pengendalian biaya, manajemen UNY-Hotel diharapkan bisa menekan biaya operasional dan sekaligus bisa melakukan persaingan harga. Oleh karena pengendalian biaya sangat diperlukan bagi UNYHotel, pihak manajemen hendaknya menetapkan strategi biaya rendah dalam menjalankan bisnisnya.

\section{E. KESIMPULAN}

Kinerja keuangan UNY-Hotel pada tahun 2011 dapat dikatakan kurang baik yang ditandai dengan (1) NPM yang dicapai sebesar 26.89\% masih jauh di bawah target yang ditetapkan yaitu sebesar $40 \%$, (2) ROA yang dicapai sebesar $6.41 \%$ di bawah tingkat bunga umum sebesar $10 \%-12 \%$ per tahun. Tingkat NPM dan ROA yang rendah mengindikasikan bahwa manajemen hotel tidak efisien dalam mengelola biaya dan aset yang dimiliki. Oleh karea itu, penting kiranya bagi manajemen hotel untuk mengendalikan biaya dan menggunakan strategi biaya rendah dalam menjalankan bisnisnya.

\section{DAFTAR PUSTAKA}

Abdul Halim dan Mamduh M. Hanafi. 2003. Analisis Laporan Keuangan. Yogyakarta: UPP AMP YKPN.

Brigham, Eugene F., Houston Joel F.(2001) Fundamentals Of Financial Management, USA: The Dryden Press.

Dwi Prastowo dan Rifka Juliaty. 2002. Analisis Laporan Keuangan: Konsep dan Aplikasi. Yogyakarta: UPP AMP YKPN.

Mulyadi. 2002. Auditing. Jakarta: Salemba Empat.

Warren, Carl S., Reeve, James W., and Fess, Philip E. 2006. Pengantar Akuntansi I. Jakarta: Salemba Empat. 